\title{
PHYSICAL AND CHEMICAL SOIL VARIABLES AND THE RELATION WITH THE COLONIZATION OF ARBUSCULAR MYCORRHIZAE IN ANGLETON (Dichanthium aristatum Benth) ROOTS
}

\section{VARIABLES FÍSICA Y QUIMICAS DEL SUELO Y SU RELACCIÓN CON LA COLONIZACIÓN DE MICORRIZAS ARBUSCULARES EN RAICES DEL PASTO ANGLETON (Dichanthium aristatum Benth)}

\author{
Alexander Pérez-C. ${ }^{1}$, Jaime De La Ossa V. ${ }^{2}$ \\ ${ }^{1}$ Dr. Sci. Universidad de Sucre, Facultad de Ciencias Agropecuarias, Grupo Bioprospección Agropecuaria, e-mail:alexpcor@ \\ yahoo.com ${ }^{2}$ Dr. Sci, Universidad de Sucre, Facultad de Ciencias Agropecuarias, Grupo de Investigación en Biodiversidad \\ Tropical. Campus Universitario Puerta Roja, A.A. 406, Sincelejo, Sucre, Colombia, e-mail: jaimedelaossa@yahoo.com
}

Rev. U.D.C.A Act. \& Div. Cient. 16(1): 71 - 78, 2013

\section{SUMMARY}

The objective of this study was to determine the colonization of arbuscular mycorrhizal fungi (AMF), associated with the roots of the angleton grass, related to physicochemical soil factors in livestock farms of four agroecological zones of the sub-region Sabana of Sucre, Colombia. The percentage of AMF colonization of roots was estimated by the staining technique, which allowed to observe under the microscope the presence of colonizing fungal structures and the subsequent determination of the percentage of colonization for sample, farms and area. With the results of the colonization percentage and the physicochemical soil analysis a correlation between th ese variables, using statistical methods and multivariate analysis, was performed. The analysis of simple correspondence showed a relationship between the presence of colonizing structures and the soil texture. The results of analysis between multiple types of colonizing structures and physicochemical soil variables showed the presence of vesicles and arbuscules in soils with high contents of calcium, magnesium and potassium and low values of nitrogen and phosphorus. There is a need for further studies in other geographical areas and other grasses to establish correlation between physicochemical soil variables and the magnitude of AMF colonization in tropical pastures in Colombia.

Key words: Micorrizae, colonization, roots, angleton, soil.

\section{RESUMEN}

El objetivo de este estudio fue determinar la colonización de hongos formadores de micorrizas arbusculares (HMA), asociadas a raíces del pasto angletón en función de factores físico-químicos del suelo, en fincas ganaderas de cuatro zonas agroecológicas, de la subregión fisiográfica de Sabanas, departamento de Sucre, Colombia. El porcentaje de colonización de HMA en raíces fue determinado mediante técnica de tinción, la cual permitió observar en microscopio la presencia de estructuras colonizantes de estos hongos y la posterior determinación del porcentaje de colonización por muestras, fincas y zona. Se realizó análisis físico-químico de las muestras de suelo. Con los resultados obtenidos del porcentaje de colonización y los análisis físico-químicos, se realizó correlación entre estas variables mediante el uso de métodos estadístico y análisis multivariados. El análisis de correspondencia simple encontró relación entre la presencia de estructuras colonizantes y la textura de los suelos. Los resultados del análisis múltiple entre tipos de estructuras colonizantes y variables físico-químicas del suelo muestran la presencia de arbúsculos y vesículas en suelos con alto contenido de calcio, magnesio y potasio y bajos valores de nitrógeno y fosforo. Existe la necesidad de seguir realizando estudios en otras zonas geográficas y con otros pastos para establecer correlación entre las variables físico-químicas de los suelos y la magnitud de la colonización de HMA en pasturas tropicales en Colombia. 
Palabras clave: Micorrizas, colonización, raíces, angletón, suelo.

\section{INTRODUCTION}

The Colombian livestock department Sucre, corresponding to the sub-region Sabana, occupies 768,600 ha of grass land and lodges a cattle population of 890,000 heads, having 56,200 established hectares with angleton grass (Dichanthium aristatum Benth), representing $7.31 \%$ of the grazing area of the Department (Viloria, 2003).

It is important to mention that the physiographic sub-region Sabanas presents a four to six months dry season, besides, human factors like degenerative environmental actions and the use of inappropriate technologies in the livestock area, have led to the physical, chemical and biological soil degradation, limiting the supply and quality of pasture and forage mainly during the dry season, generating in this subregion the transhumance to lowland of the Mojana and San Jorge sub-regions (Aguilera, 2005).

The rhizosphere is a heterogeneous, continuous and natural habitat in which different types of interactions occur between soil microbes and plants. The beneficial plant-microbe interactions in the rhizosphere are the primary determinants of plant health and soil fertility (Jeffries et al. 2003). The widespread mycorrhization together with the fossil record indicate that plants and fungi have evolved in mycorrhizal relationship since the colonization of land by early plants (Strullu \& Strullu, 2007). It is estimated that approximately 95\% of the known vascular plants species on earth, including pastured are colonized by arbuscular mycorrhizal fungi which belong to the Phyllum Glomeromycota in different ecosystems (Schübler et al. 2001, Strullu \& Strullu, 2007, Miransari et at. 2009, Pérez \& Vertel, 2010).

Arbuscular mycorrhizal fungi under phosphate-limited conditions can favor plant community development, nutrient uptake, water relations and aboveground productivity and act as bio-protectants against pathogens and toxic stresses (Jeffries et al. 2003; Toljander et al. 2006).

Although the importance of the mycorrhizal symbiosis is worldwide recognized, there are many aspects on the structure and operation of communities in tropical agroecosystems that have not been studied. In Colombia, most of the research has been related to the benefits of the symbiosis in different hosts, especially on aspects of productivity, plant nutrition and fertilizer substitution (Rey et al. 2005), but there is little work to assess the mycorrhizal colonization influenced by physical and chemical soil parameters of livestock farms. Studies on variables that influence the arbuscular mycorrhizal fungi root colonization level associated to angletón pastures and other species of economic interest in the Colombian Caribe coast under specific soil conditions and grazing and management of these agroecosystems are still scarce. Further studies to link the biological and physical aspects of the soil with the chemical parameters and their relationship with the quality and productivity of ecosystems are required.

\section{MATERIALS AND METHODS}

The study was carried out in the Municipality of CorozalSucre-Colombia, located in the physiographic sub-region of the Sabana, in the slope of the Mountains of Maria to the depression of the low Cauca and San Jorge rivers, at $8^{\circ} 55^{\prime}$ and $9^{\circ} 19^{\prime}$ North and between $75^{\circ} 25^{\prime}$ and $74^{\circ} 42^{\prime}$ East, with an average annual temperature of $28^{\circ} \mathrm{C}$, precipitation of $1,105 \mathrm{~mm}$, annual relative humidity of $80 \%$, and altitude between 174 to $200 \mathrm{~m}$ besides presenting a dry season of 4 to 6 months.

Forty eight livestock farms cultivated with angletón pasture in the municipality of Corozal (Sucre) were sampled, localized in agroecological zones classified according land use and management capacity, according to IGAC (1998; POT, 2002): zone 1 (III sc - IV hs), zone 2 (VII sc - IV esc), Zone 3 (VI sc- VI esc) and Zone 4 (VII sc- VII esc). The characteristics of the main agro ecological analyzed zones are the following:

Zone 1. (subclass III sc - Iv hs). Soils with a slightly sloping flat relief, slope ranging from 1-3 and 3-4\%; moderately deep, imperfectly drained, moderately fine texture and permeability, moisture retention slow average, moderately acidic to neutral reaction, high availability of $\mathrm{Ca}, \mathrm{Mg}$ and $\mathrm{K}$, low in available phosphorus in organic matter content and low to medium low moderate fertility. The limitations of subclass III SC are: the effective depth to moderate clay horizons limited by compacted, low permeability, low air capacity, low organic matter content and available phosphorus and low humidity. Currently, there are natural grasses, corn, cassava and cassava association / ñame set forth in this subclass.

The soils of subclass Ivhs are composed of poorly drained soils, shallow to very shallow, clay, low permeability, high moisture retention, sticky, plastic, moderately to strongly acidic reaction, medium high contents of exchangeable cations, percentages of phosphorus available and low organic matter, moderate current fertility. In the current conditions suitable for rice and natural grasses; excess moisture resistant.

Zone 2. (Subclass VII sc - Iv esc). The subclass VII SC soils are strongly undulating, with slopes of 12 to $25 \%$, show slight erosion, well drained, moderately deep, with a moderate to fine texture, medium moisture retention, moderate permeability. Chemically, soils have a acidic to neutral reaction and a moderate fertility. The main limitations are strongly undulating slopes, the low content of nitrogen, 
phosphorus and organic matter. Part of this area is occupied by cattle ranching on natural pastures and stubble.

The soils of subclass $I V$ esc are located in areas heavily undulated to undulated, with slopes of 12 to $25 \%$ and some sections with 1 to $12 \%$. They are moderately deep, mostly clay with inclusions of moderately fine textured, well-drained, medium to high moisture retention, suffer cracking during the dry season. The chemical characteristics indicate that I they have an acidic to slightly alkaline reaction, are high in calcium, magnesium and potassium and organic matter content and low in available phosphorus. Current use is extensive grazing on natural pasture; in some sectors cotton, corn, sorghum and cassava is grown.

Zone 3. (subclass VI sc - VI esc). The VI subclass $s c$ has soils with slopes between $12-25 \%$ and $25-50 \%$, the soils are shallow to moderately deep, coarse loamy to loamy, well drained to excess. Susceptible to erosion, good permeability, medium to low moisture retention, neutral to slightly acidic reaction and moderate fertility. The limitations for the management and use of these soils are the low availability of water with scarce effective depth, available phosphorus content, low nitrogen and organic matter. The current use of the land is livestock with natural pasture as well as crops such as maize, cassava, yams and some fruits.

In the subclass cluster VI esc soils with slopes of 12 - $25 \%$ and $25-50 \%$, soils with very varied morphological, physical and chemical characteristics; effective depth varies from shallow to moderate. Thick loam to loamy, or clayey fine, low to moderate fertility and acid reaction to neutral. The limitations of the subclass are of chemical nature with phosphorus and macronutrients deficiency and high aluminum content, limiting their ability to preserve vegetation cover. Maintenance of natural grass requires stringent precautions, avoiding overgrazing to prevent the progress of erosion.

Zone 4. (subclass VII sc - VII esc). Part of the subclass VII SC are soils with slopes up to 12 to $25 \%$, slightly eroded; limited by very superficial layers of gravel; they have strongly acidic reaction, base saturation, low phosphorus and organic matter content. The use for crop cultivation is low due to the shallow depth and low effective fertility. Pastures are the best current use of these soils. Besides, they are used for extensive livestock management and small subsistence crops.

In the subclass VII esc has slopes of 1-12, 12-25, 25-50 and $50-75 \%$, with moderate to severe erosion. The soils are shallow to deep, well drained, with a low structural stability, moderate permeability, low to medium moisture retention, slightly acidic to neutral reaction and low to moderate fertility. Severe limitations presented by steeply dipping slopes susceptible to erosion and in some cases, low fertility. These lands are suitable for agriculture and they have little pastures.
Best approach is forest, but as much of the area is in pasture and stubble, it is necessary to take measures to prevent the increase of erosion.

Sampling: A plastic cylinder of $3.8 \mathrm{~cm}$ in diameter and $25 \mathrm{~cm}$ in length was used to take samples at of $0-20 \mathrm{~cm}$ depth, inserting, rotating and removing the cylinder with the sample (soil and roots). From 15-20 samples per farm were taken, they were homogenized to form a $2,000 \mathrm{~g}$ example. Two subsamples $(1,000 \mathrm{~g}$ each) were used to determine the percentage of AMF colonization in roots and a subsample of $1,000 \mathrm{~g}$ to analyze the physical-chemical properties of the soil: Na, P, N, pH, cation exchange capacity (CEC), Ca, Mg, $\mathrm{Al}, \mathrm{K}$ and organic matter (OM).

Percentage of colonization: Collected samples were packed in plastic bags and transported to the laboratory and stored at $4^{\circ} \mathrm{C}$ until analysis. The colonization percentage was determined by coloring the roots and further microscopic observation were made to estimate root colonization percentage. In each field the colonizing structure (field's positive) of arbuscles, vesicles, hyphae and spores present within each root were observed. The results are expressed in percentage (Pérez et al. 2011).

Statistical analysis: After determining the percentage of root colonization it was correlated with the agroecological zone and livestock farms (treatment) through an analysis of variance (ANOVA) and a test of comparison, Tukey at $5 \%$ significance. Physical and chemical parameters of soil evaluated in the sampleds were $\mathrm{pH}$, organic matter, phosphorus, potassium, nitrogen, calcium, magnesium and texture.

Statistical relationships between physical-chemicals parameters and colonization were determined by multivariate statistical methods. The correlation between colonizing structures (hyphae, spores, vesicles and arbuscules) and treatment was made through a simple correlation analysis (ACS). The classification of farms sampled in different areas was performed with agglomerative cluster analysis of Euclidean distances that is linked to the method of Ward (Cabarcas \& Pardo, 2001), taking into account information from the ACS. To relate the physical-chemical soil variables to the livestock a Multiple Factor Analysis for frequency table for continuous variable (Zar, 1996) was used. All numerical data were analyzed with the statistical program $\mathrm{R}$ (Rural Development Core Team, 2009).

\section{RESULTS AND DISCUSSION}

Given the confidence intervals of $95 \%$ for physical-chemical parameters in livestock farms, $\mathrm{pH}$ values showed the soils to be strongly acidic to strongly alkaline, with a medium and low phosphorus, organic matter, nitrogen and sodium content; and high to medium calcium, magnesium and potassium values (Table 1). 
Table 1. Confidence intervals averaged $95 \%$ for chemical parameters of soils with angleton pasture in analyzed livestock farms.

\begin{tabular}{|c|c|c|c|c|c|c|c|c|c|c|}
\hline \multirow{2}{*}{ Indicator } & \multirow{2}{*}{$\mathrm{pH}$} & M.O & $N$ & \multirow{2}{*}{$\begin{array}{c}\mathrm{P} \\
\mathrm{ppm}\end{array}$} & $\mathrm{CIC}$ & $\mathrm{Na}$ & $\mathrm{Al}$ & K & $\mathrm{Ca})$ & $\mathrm{Mg}$ \\
\hline & & \multicolumn{2}{|c|}{$\%$} & & \multicolumn{6}{|c|}{$\mathrm{Cmol}_{\mathrm{Kg}} \mathrm{K}^{-1}$ suelo } \\
\hline IC 95\% & 4.6-8.6 & $0.0-3.0$ & $0.0-0.013$ & $0.0-17.5$ & $5.2-44.6$ & $0.0-2.66$ & - & $0.0-0.94$ & $0.0-25.1$ & $0.0-11.52$ \\
\hline
\end{tabular}

pH: (method P/V relation 1:1); M.O: organic matter, method Walkey-Black-indirect organic carbon; P: Phosphorus, modified method Bray II; CIC: cation exchange capacity, method ammonium acetate $1 \mathrm{~N}$ and neutral; $\mathrm{N}$ and $\mathrm{K}$ : atomic absorption; Ca and Mg: method compleximetric.

The results obtained of ANOVA indicate no significant differences ( $\mathrm{p}$-value $=0.213$ ) between colonization and agroecological zones in agroecological zones and reconfirmed this result with the Tukey test (Figure 1a and 1b).
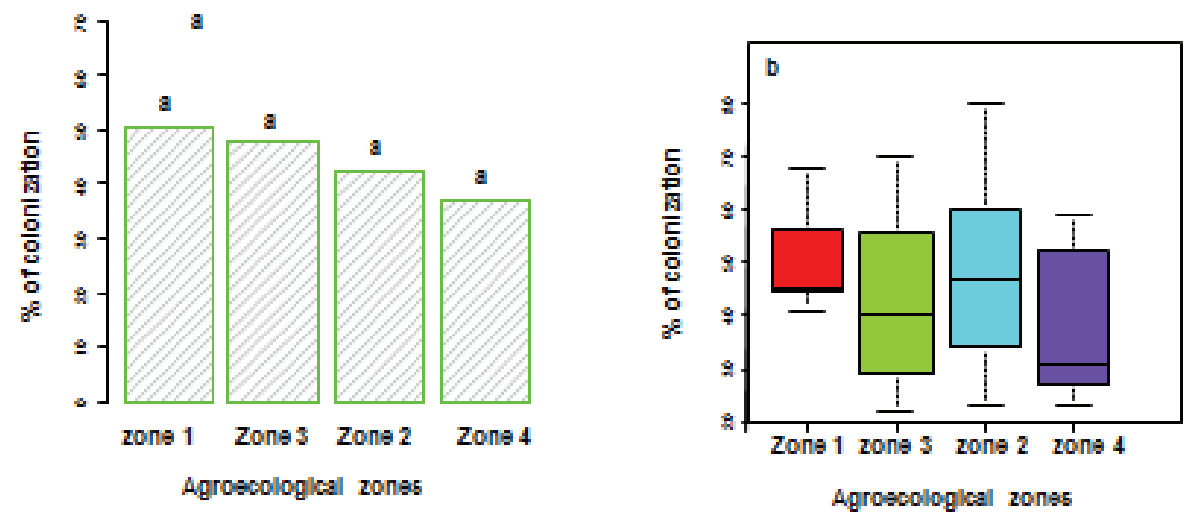

Figure 1. Tukey test (a) and Bloxpot's graph results (b), for colonization AMF in angleton roots.

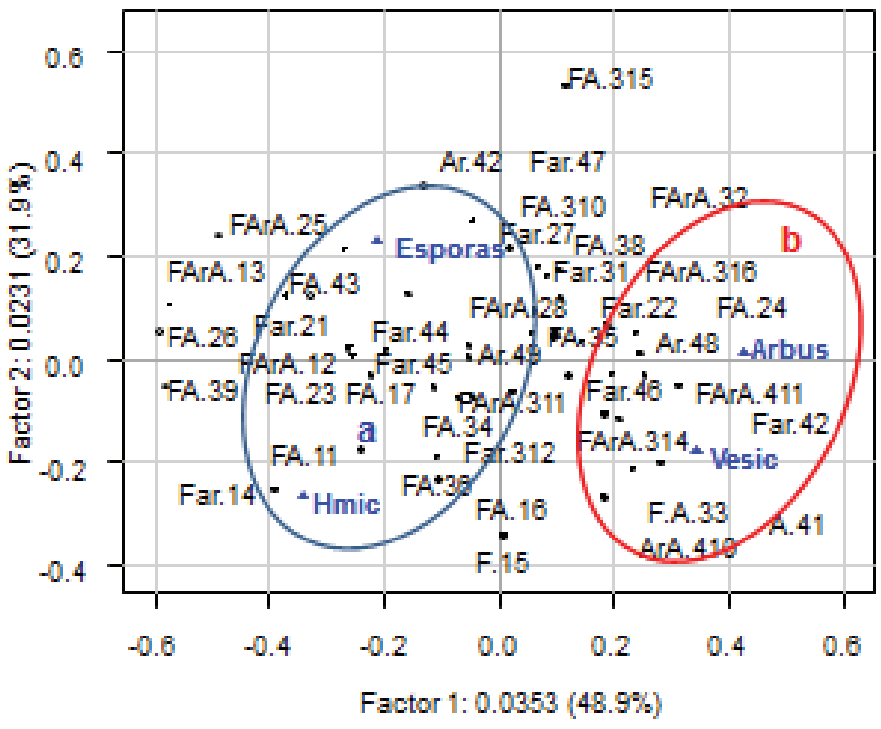

Figure 2. Simple correlation analysis for colonization (hyphae, spores, vesicles and arbuscules) of AMF in angleton grass' roots in relation to soil texture of livestock farms. HMIC: mycorrhizal hyphae, Arbus: Arbuscules, Vesic: Vesicles. F: franco, FA: Franco clay, Far: Franco sandy, A: clay, Ar: sandy. 
The simple correlation analysis revealed a relationship between patterns of colonization (hyphae, spores, vesicles and arbuscles) of AMF and soil texture (Figure 2). Livestock farms that are close to the first factor (circle A) have higher rates of colonization predominantly arbuscules and vesicles in angleton roots. Farms next to the second factor (circle B) had higher rates of colonization with hyphae and spores presence in the pasture roots. The graphed results show a correlation between colonization patterns in relation to livestock farms type having a particular soil texture.
Figure 3 displays the agglomerative classification analysis of soil texture types found in the different analyzed livestock farms. Hyphae were observed in farms with soil textures of sandy loam; the greater abundance of spores were found on farms with sandy loam to clay loam, while on farms where arbuscules and vesicles were found, dominated the soils of sandy clay texture. In farms where both spores and arbuscules were observed a clay texture was predominant.

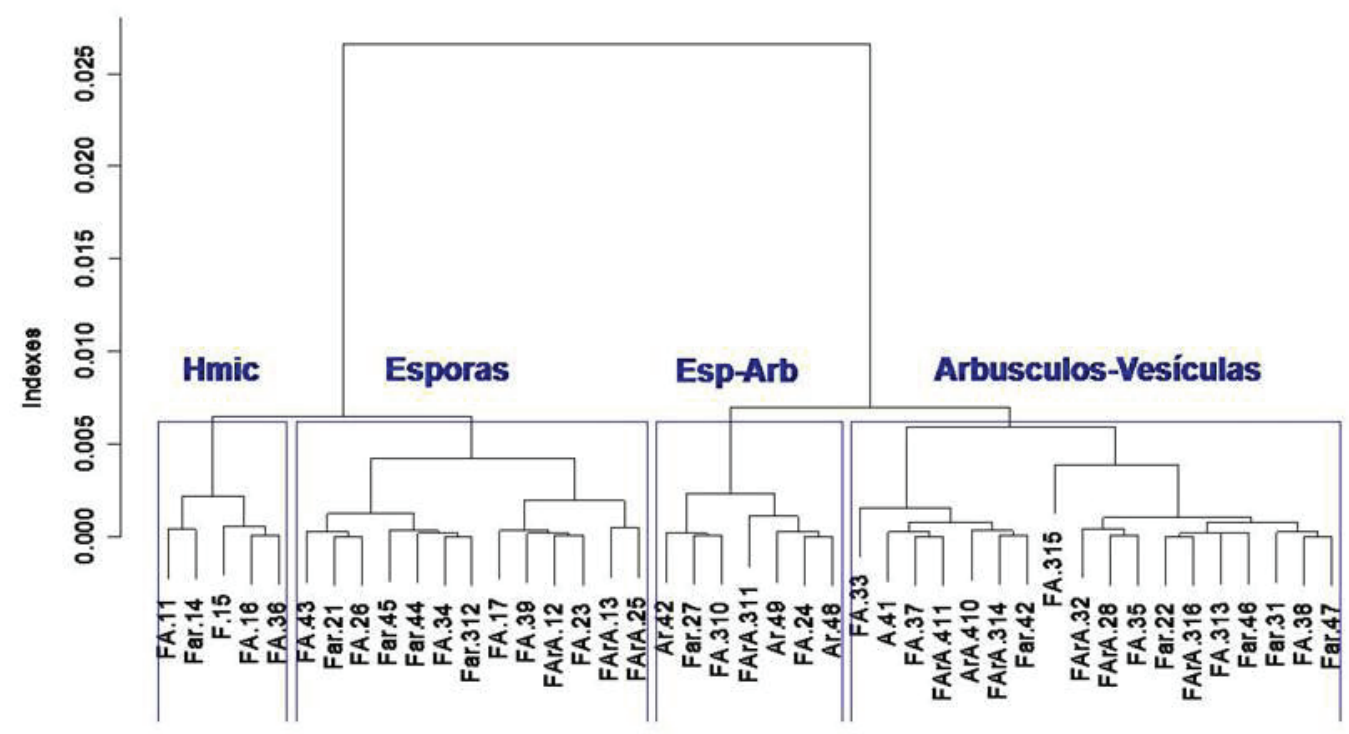

Figure 3. Agglomerative classification analysis of mycorrhizal colonization patterns in roots by cattle livestock' soil texture. HMIC: mycorrhizal hyphae, Esp-Arb: spores and arbuscules.

Multiple factor analysis among soil physical-chemical parameters and mycorrhizal colonization patterns in Angleton's roots on sampled farms, show that the first component is related to high levels of magnesium and potassium and low levels of $\mathrm{Ca}$ and $\mathrm{N}$, phosphorous, sodium, indicating that farms that have soils with these characteristics, present patterns of colonization with vesicles and arbuscules abundance in roots $(\lambda=1.3$, account for $27 \%$ of the total variability of the data). The second component of the system is related to a low cation exchange capacity, to low levesl of organic matter, of calcium and low $\mathrm{pH}$, having a greater abundance of arbuscules in angleton roots, while in farms with moderate levels of these parameters, hyphae and spores associated to the roots were detected.

The colonization patterns observed in pasture angletón follow the order from hyphae, spores, blisters and arbuscules. In Colombia, there are no parallel works about this grass species. However, Pérez \& Vertel (2010) observed the presence of arbuscules, hyphae, spores and vesicles in Colosana root pasture in the municipality of Corozal, Sucre.

There are scarce worldwide research results on the effect of environmental variables about colonization of AMF in roots of tropical pastures. As an attempt to establish correlations between some physicochemical parameters in the soil of cattle ranches in the Colombian Caribbean coast, Pérez et al. (2010) using statistical models through the analysis of a multiple logistic regression in order to determine the colonizing percentages of AMF in angletón grass roots, found that nitrogen, calcium and potassium were chemical variables that better explain the variation of the colonizing event of these fungi, present in the roots of the grass.

Other studies have shown that the arbuscular mycorrhizae have a great colonizing capacity within $\mathrm{pH}$ ranges from 2.7 to 9.2. For the colonizing of these mycorrhizae to occur, a soil $\mathrm{pH}$ ranging from 4.5 to 5.5 is required (Alloush et al. 2000). 


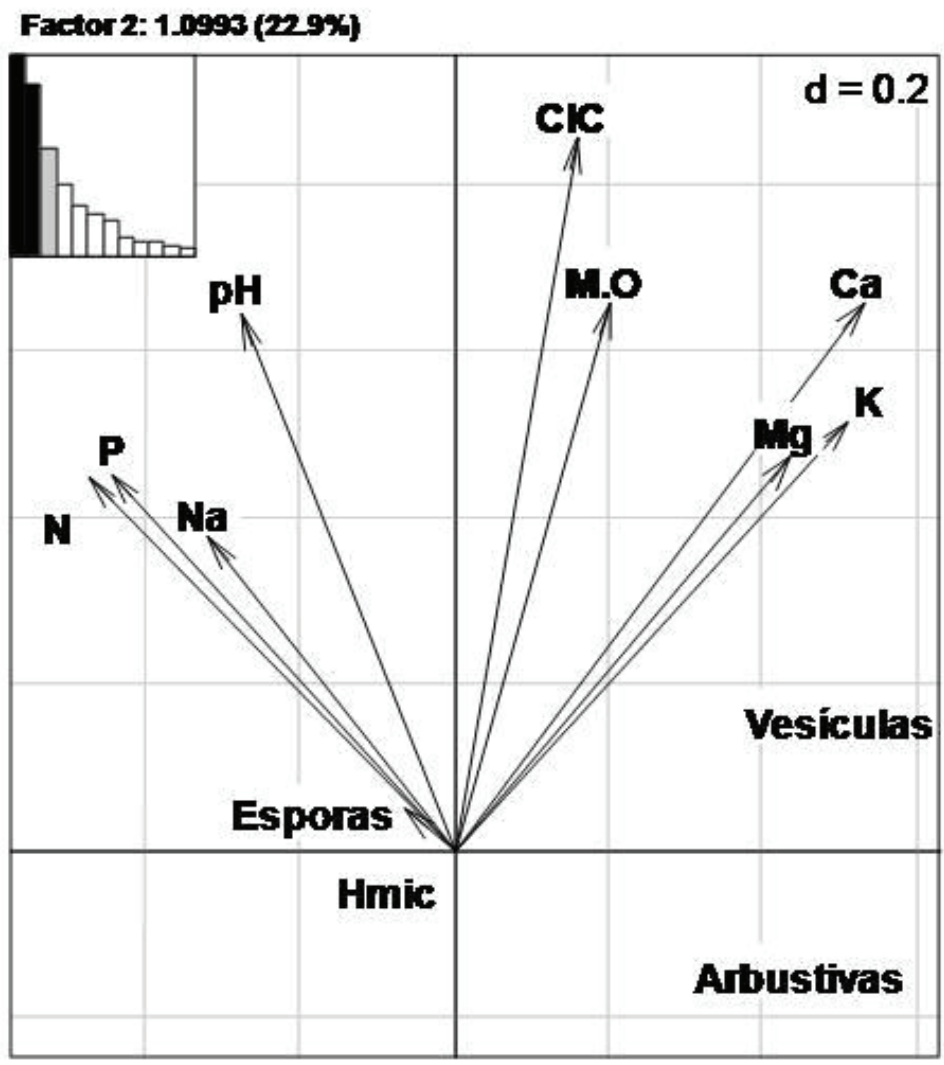

Factor 1: 12a91 (26.9X)

Figure 4. Multiple factor analysis among environmental variables and arbuscular mycorrhizal colonization patterns on angletón grass' roots. HMIC: mycorrhizal hyphae, Vesic: vesicles and Arbus: arbuscles.

This chemical parameter has influence on the solubility and availability of elements towards the plants roots, including iron, magnesium, copper, zinc and toxic amounts of aluminum. High levels of phosphorus can inhibit the colonizing percentage of mycorrhizae as well as the growing of plants.

So far, several works have proposed that the application of nitrogen (in the form of nitrate and ammonium) to the soil can have a certain inhibitory or stimulating effect for the colonizing of arbuscular mycorrhizae (Cardoso \& Kuyper, 2006). It has been proven that nitrogen present in the form of ammonium has a suppressive effect on the colonizing of these mycorrhizae, due to the change in the $\mathrm{pH}$ of the rhizosphere (Cardoso \& Kuyper, 2006). The diversity in the forms of inorganic nitrogen existing in the soil affects the percentage of colonizing, the root length and the presence of colonizing structure types such as arbuscles and blisters (Valentine et al. 2002).

Applications of high levels of $\mathrm{MgSO}_{4}$ resulted in reduced root colonization and sporulation by Glomus sp. of sweet potato and onion in aeroponic and sand culture, respectively. Magnesium application depressed tissue-Ca levels. With lower $\mathrm{Ca}$ in the tissue, colonization was reduced from $>$ $30 \%$ of root length to $10 \%$, and sporulation from 1200 to ca. 200 spores per plant, 10 weeks after transplantation and the start of nutrient application. These effects on colonization and sporulation were independent of changes in tissue-P concentration. High Mg/low Ca tissue concentrations induced premature root senescence, which may have disrupted the mycorrhizal association (Jarstfer et al. 1998).

Information about $\mathrm{AMF}$ and mycorrhizal host plant responses at low $\mathrm{pH}(<5)$ is limited. Root colonization is generally less in low than in high $\mathrm{pH}$ soils. Maximum enhancement of plant growth in acid soil varies with $\mathrm{AM}$ fungal isolate and soil $\mathrm{pH}$, indicating adaptation of $\mathrm{AM}$ isolates to edaphic conditions. The absorption of many mineral nutrients such as $\mathrm{P}$ and $\mathrm{Zn}$ by plant roots colonized by mycorrhizae in acid soil is increased and the minerals which concentration is enhanced are those commonly deficient in acid soils ( $\mathrm{Ca}, \mathrm{Mg}$, and $\mathrm{K})$. Some AM 
fungal isolates are effective in overcoming soil acidity factors, especially $\mathrm{Al}$ toxicity, that restricts plant growth at low $\mathrm{pH}$ (Clark, 1997; Clark \& Zeto, 2000).

Although there is a considerable amount of information about the in vitro factors that have an influence on the colonizing of AMF in different soil types and agricultural crops, existing information in situ about the effect of physical and chemical parameters on the presence and colonizing structures of these fungi in specific agroecosystems in Colombia is scare. The relevance of $\mathrm{AMF}$ in different crops as a biological resource which management and conservation, as well as its effects on the vegetable productivity and sustainability, represent environmental benefits since it improves the physicochemical and biological soil conditions when it interacts with a variety of macro and microorganisms in the rhizosphere (Barrer, 2009). The survival of plants in unfavorable or stressing environments can be the consequence of multiple factors and strategies, one of them being the symbiosis based on arbuscular mycorrhizae (Tao \& Zhiwei, 2005).

Although there are preliminary results on the evaluation of the percentage of AMF colonization on the pasture Colosoana according to physical and chemical parameters, is still required much more researches to allow to conclusive correlate these physical and chemical parameters with efficiency in colonization by these fungi in edaphic conditions of livestock farms in the department of Sucre. Subsequent studies which evaluate the effect of AMF colonization on other grass species, important for cattle feeding, and other research which relates the effect of AMF colonization to the physical and chemical soil parameters and determines the mycorrhizal needs for efficient colonization are required.

Acknowledgements: The researchers thank the Universidad de Sucre, Colombia and to Cattle breeder association of the Department of Sucre. Conflict of interests: The manuscript was prepared and revised with the participation of all the authors who declare that no conflict of interests exist that put in risk the validity of the presented results. Financing: This study was financed with contributions of the University of Sucre, Colombia.

\section{BIBLIOGRAPHY}

1. AGUILERA, M.M. 2005. Documento de trabajo sobre economía regional. Economía Regional: La Economía del Departamento de Sucre: Ganadería y Sector Público. Sincelejo: Banco Ganadero. Bogotá, Colombia. 129p.

2. ALLOUSH, G.A.; ZETO, S.K.; CLARK, R.B. 2000. Phosphorus source organic matter and arbuscular mycorrhizal effects on growth and mineral acquisition of chickepea grown in acidic soil. J. Plant. Nutr. 23(9):1351-1369.
3. BARRER, S.E. 2009. El uso de hongos micorrízicos arbusculares como una alternativa para la agricultura. Rev. Biotecn. Sector Agropec. Agroindustr. 7(1):123133.

4. CABARCAS, G.; PARDO, C. 2001. Métodos estadísticos multivariados en investigación social: Cursillo, Simposio de estadística, Universidad Nacional, departamento de Estadística. Santa Marta, Colombia. Disponible desde Internet en: http://www.docentes. unal.edu.co/cepardot/docs/simposiosestadística/ (con acceso 06/09/2010).

5. CARDOSO, I.M.; KUYPER, T.W. 2006. Mycorrhizas and tropical soil fertility. Agric. Ecosyst. Environ. 116(12):72-84.

6. CLARK, R.B. 1997. Arbuscular mycorrhizal adaptation, spore germination, root colonization and host plant growth and mineral adquisition at low pH. Plant Soil. 192(1):15-22.

7. CLARK, R.; ZETO, S. 2000. Mineral acquisition by mycorrhizal plants. J. Plant. Nutr. 23(7):867-902.

8. JEFFRIES, P.; GIANINAZZI, S.; PEROTTO, S.; TURNAU, K.; BAREA, J.M. 2003. The contribution of arbuscular mycorrhizal fungi in sustainable maintenance of plant health and soil fertility. Biol. Fertil. Soils. 37(1):1-16.

9. INSTITUTO GEOGRÁFICO AGUSTÍN CODAZZI (IGAC). 1998. Estudio general de suelos y zonificación de tierras. Departamento de Sucre. Sincelejo: Instituto Geográfico Agustín Codazzi. Bogotá, Colombia. 89p.

10. JARSTFER, A.G.; FARMER-KOPPENOL, P.; SYLVIA, D.M. 1998. Tissue magnesium and calcium affect arbuscular mycorrhiza development and fungal reproduction. Mycorrhiza. 7(5):237-242.

11. PÉREZ, C.A.; VERTEL, M. 2010. Evaluación de la colonización de micorrizas arbusculares en Botrhriochloa pertusa (L) A. Camus. Rev. MVZ Córdoba. 15(3):2165-2174.

12. PÉREZ, C.A.; ROJAS, S.J.; MONTES, V.D. 2011. Hongos formadores de micorrizas arbusculares: una alternativa biológica para la sostenibilidad de los agroecosistemas de praderas en el Caribe Colombiano. Rev. Col. Cienc. Anim. 3(2):366-385.

13. PÉREZ,A.;ROJAS, J.;FUENTES, J.2010. Determinación de un modelo logístico para evaluación in situ de la colonización de micorrizas en pasto Dichanthium aristatum (L). Rev. Col. Cienc. Anim. 2(1):73-84. 
14. PLANDE ORDENAMIENTO TERRITORIAL (POT). 2002. Diagnóstico del Municipio de Sincelejo. Sincelejo: Plan de Ordenamiento Territorial. Sincelejo, Sucre, Colombia. 112p.

15. RURAL DEVELOPMENT CORE TEAM. 2009. Language and Environment for Statistical computing, $\mathrm{R}$ Foundation for Statistical Computing. Disponible desde Internet en: http://www.R-project.org (con acceso 10/07/2010).

16. REY, A.M.; CHAMORRO, D.; RAMÍREZ, M. 2005. Efecto de la doble inoculación de rizobios y micorrizas sobre la producción y calidad del forraje de Leucaena leucocephala. Rev. Corpoica. 6(2): 52-59.

17. SCHÜBLER, A.; SCHWARZITT, D., WALKER. 2001. A new phylum, the Glomeromycota: Phylogeny and evolution. Mycol. Res. 105:1413-1421.

18. TAO, L.; ZHIWEI, Z. 2005. Arbuscular mycorrhizas in a hot and arid ecosystem in southwest China. Appl. Soil Ecol. 29(1):135-141.
19. TOLJANDER, J.F.; ARTURSSON, V.; PAUL, L.R.; JANSSON, J.K.; FINLAY, R.D. 2006. Attachment of different soil bacteria to arbuscular mycorrhizal fungal extraradical hyphae is determined by hyphal vitality and fungal species. FEMS Microbiol. Lett. 254(1):34-40.

20. VILORIA, H.J. 2003. Documento de trabajo sobre economía regional: La ganadería bovina en las llanuras del Caribe Colombiano. Banco de la República. Cartagena de Indias, Colombia. 86p.

21. VALENTINE, A.J., OSBORNE, B.A., MITCHELL, D.T. 2002. Form of inorganic nitrogen influences mycorrhizal colonization and photosynthesis of cucumber. Scien. Hort. 92(3-4):229-239.

22. ZAR, J.H. 1996. Bioestatistical Analysis. $3^{\text {rd }}$ edition. Prentice-Hall, Inc. (Englewood Cliff, N.J). 663p.

Received: 25 October 2011

Accepted: 28 February 2013 